\title{
Agency-structure dynamics in an indigenous mathematics education community in times of an existential crisis in education
}

\author{
Piata Allen ${ }^{1}$ (i) $\cdot$ Tony Trinick ${ }^{1}$ (D)
}

Accepted: 25 July 2021/ Published online: 27 August 2021

(c) The Author(s), under exclusive licence to Springer Nature B.V. 2021

\begin{abstract}
This article is a synthesis of the historical account of the ongoing suppression of Māori indigeneity (language and cultural knowledge) in mathematics education for over 100 years. During that time, Māori, the Indigenous people of Aotearoa New Zealand, have been ravaged by the effects of globalisation as an outcome of colonisation, resulting in loss of property, linguistic, and cultural rights, that have been compounded by the damaging effects of diseases that have cumulatively sustained negative socioeconomic and education outcomes to this day. The COVID-19 pandemic, which arrived on Aotearoa New Zealand shores in February 2020, exposed and further exacerbated the deep inequities that already existed due to the legacy of assimilation policies. This article draws on Bourdieu's notions of capital, habitus, and field to frame our analysis of the capacity and potential for Māori to act as agents within, and against, multiple cultural and structural pressures that have impacted the historical development of Māori-medium mathematics education, and the capacity of the Māori-medium mathematics community to cope while schools were closed during the COVID-19 pandemic. This article reveals that despite some recent positive structural changes in response to the emergence of Māori-medium schooling in the 1980s, and partly due to the high status of mathematics educationally, many structural challenges remain. In 2020, in response to having to deliver mathematics education remotely, the Māori-medium community, including parents, teachers, and associates, used their individual and collective agency to overcome the structural barriers created by physical school closures.
\end{abstract}

Keywords Bourdieu $\cdot$ Sociology $\cdot$ COVID-19 pandemic $\cdot$ Indigenous mathematics education $\cdot$ Inequalities

Piata Allen

p.allen@auckland.ac.nz

Tony Trinick

t.trinick@auckland.ac.nz

1 The University of Auckland, Auckland, Aotearoa New Zealand 


\section{Background}

Marginalised Indigenous groups around the world continue to be challenged in a number of unique ways in the teaching and learning of mathematics. While contexts differ from country to country, there are many similar challenges, such as the role of their Indigenous knowledge and language in mathematics education in colonised countries (Trinick, 2015). These challenges are compounded by the often fragile infrastructure and capacity of the community to provide a robust mathematics education programme. The issues facing Indigenous groups' abilities to provide an effective mathematics education programme have been further exacerbated by the current pandemic currently sweeping the world. This article discusses how the pandemic has impacted the ability of Māori, the Indigenous people of Aotearoa New Zealand (NZ), to provide an effective mathematics education programme, particularly during lockdown periods.

The impacts of pandemics and the importation of foreign diseases linger in the historical memory of Māori, dating back to the 1918 pandemic. In 2020, Māori, the rest of the Aotearoa NZ population, and most of the world faced another terrifying global pandemic ravaging humanity. While technology, health services, and Māori standards of living have considerably improved since the 1918 pandemic, Māori, like many Indigenous and marginalised groups around the world, were rightfully concerned considering the trauma of the previous pandemic (King et al., 2020). The COVID-19 pandemic in Aotearoa NZ began when the first case of COVID-19 was reported on February 28, 2020. Two days later, the Prime Minister, the Rt Hon Jacinda Ardern, on the advice of science and health professionals, ordered that everyone coming into the country would have to self-isolate for 14 days (Ministry of Health, 2020). It was among the earliest and toughest self-isolation measures in the world and would lead to a complete lockdown 1 week later. Other than essential workers, all other citizens were instructed to stay at home (which was colloquially referred to as "in their bubble"). Internal travel was severely restricted, and all schools and educational institutes were closed (Ministry of Health, 2020). To date, these measures have limited the number of deaths to 26 , but the lockdown period had a significantly more negative impact on families who were learning and teaching in the medium of the Māori language (Māori-medium) in contrast to those learning in English-language (English-medium) contexts.

Aotearoa NZ is a small island nation located in the South Pacific Ocean. Aotearoa is one of the Māori names for the country and is now used interchangeably with New Zealand as the official name of the country. In this article, the term Aotearoa NZ is used to identify the country. Māori people belong to one or more interrelated tribes, and Māori oral histories place Māori occupation of Aotearoa NZ to more than 1000 years prior to the arrival of the first European explorers (Smith, 2000). Māori speak an Eastern Polynesian language, and over time, dialects have developed according to the village or island origins of the speaker, and to the relative isolation of local tribal populations (Benton, 1991). Unlike other Indigenous language contexts, the tribal dialects are mutually intelligible (apart from some lexical items) (Bauer, 1993), greatly aiding national language revitalisation efforts and the eventual development of mathematics education in the Māori language beginning in the 1980s. Both of the authors of this article are Māori and have been involved in the development of Māori-medium mathematics since the 1980s. Piata's involvement was first as a student in one of the earliest Māori-medium schools, and more recently, in Māorimedium teacher education and research. She also participates in Māori-medium education as a parent of a Māori-medium primary school student and belongs to the Ngāti (family of) 
Kahungunu and Ngāti Apa tribes. Tony helped establish the discipline of Māori-medium mathematics and continues to contribute to curriculum and assessment developments and teacher education. He belongs to the Whānau-ā-Apanui tribe.

The next two sections provide a historical account of the suppression, and then revitalisation, of the Māori language and culture to contextualise the recent challenges faced by the Māori-medium community in providing Māori language mathematics instruction during the COVID-19 pandemic. We draw on the work of Bourdieu $(1977,1984,1999)$ and his ideas of linguistic capital to understand why things are the way they are.

\section{Historical legacy of mathematics education in colonial schooling}

This section presents an overview of the structural exclusion of the Māori language and culture in schooling and mathematics education as part of a wider set of social practices up until the 1980s. In this regard, Māori have been involved in an ongoing agentic struggle with the State for generations to maintain the Indigenous language, culture, and knowledge systems of Aotearoa NZ in schooling against colonial linguistic and cultural hegemony. One of the first acts British colonists established when they gained political control in the mid-nineteenth century was to ban Māori language and culture from schooling. This was because the hegemonic function of schooling at that time was to provide a formalised context to assimilate Māori communities into European beliefs, attitudes, and practices, with the intent to "civilise" the Māori population and support the creation of a monolingual nation-state (Trinick et al., 2015). This is akin to Bourdieu's (1991) critical analysis of the role of the State, and its key institutions such as education, in promoting national languages at the expense of the minority Indigenous language(s).

Although Māori language and culture were excluded from schooling, these were still nurtured throughout the nineteenth and twentieth centuries in rural Māori communities (May \& Hill, 2005), and Māori was still the predominant language spoken in Aotearoa NZ by Māori (Benton, 1991). Despite the English-only model being a quintessential example of linguistic assimilation in schooling up until the 1960s, Māori were resilient in their quest to hold fast to their language in their communities (May \& Hill, 2005). Many Māori children had become bilingual, speaking te reo Māori (the Māori language) at home and English at school (Benton, 1991).

The health of the Māori language was significantly compromised in the twentieth century with language loss accelerating after World War II (Benton, 1991). From the 1950s onwards, the Māori population rapidly became urbanised in response to structural factors including economic and social struggles in rural areas (Benton, 1991), and explicit social, educational, and employment policies related to a wider economic drive for a larger urban labour force (Barber, 1986). Once Māori migrated to urban areas, there was a greater likelihood of Māori mixing with English-language speakers in most domains (other than the home), as English was the only language permitted (Chrisp, 2005; Trinick et al., 2015). The change in the status of the Māori language to a low-status language contributed considerably to the language shift to English in Māori communities. One of the outcomes of this process was that by the 1970 s, only approximately $18 \%$ of the Māori community were fluent Māori language speakers, with most being elderly, and less than 5\% of Māori schoolchildren speaking the Māori language (Benton, 1979).

While language shift is often couched as "voluntary" or simply a "rational choice", particularly by proponents of majority languages (Edwards, 1994), it is rather the result of a 
complex array of wider social forces which have, over time, forcibly proscribed the minority language from key domains such as education and the teaching of mathematics. Not surprisingly perhaps, speakers of minority languages eventually internalise the associated negative attitudes towards these languages, a process Bourdieu describes as mécconnaissance or misrecognition, which is a key contributor to eventual language shift (May, 2011). By the late 1970s, the Māori language was recognised as endangered (Fishman, 1991) and threatened with possible extinction (Spolsky, 2003). This realisation provided the impetus for Māori communities to exercise their collective agency and alter the impending trajectory of language, culture, and knowledge loss through community-led language revitalisation structures.

\section{The dynamics of agency and structure}

This article engages in the agency-structure sociological debate, particularly drawing on the work of Bourdieu $(1977,1984,1999)$. Bourdieu's theory of practice is useful for sociologists of (mathematics) education who are interested in understanding why things are the way they are. For example, Bourdieu argues a historicised (diachronic) approach is necessary to highlight and explore how particular languages come to accrue status and power over time in particular social and political contexts (including education), most often at the specific expense of other languages (May, 2011). Bourdieu also offers theories of social change that integrate agency and structure that enhance our accounting for how macrostructures and micro-agency interplay and cohere in promoting and/or limiting the development of mathematics education in Indigenous languages. We also draw on Nancy Fraser's (2003, 2005) ideas on recognition, representation, and distribution. While their theories point to different starting points and projects, both Fraser and Bourdieu are concerned with social inequalities and how they may be understood, challenged, reduced, or overcome.

Concepts of agency involve an individual's capacity to act of their own free will to make autonomous choices (Barker, 2005). Seen from this perspective, Māori individual capacity and interactions with others to construct (or reconstruct) their world could be more influential on the development of Māori language mathematics instruction than the influences of the wider social structure. If taking the agency view of this debate, social structure is a consequence of the actions and dynamics of interacting individuals; agency is significant. However, a tension exists in that agency is not applied in isolation of historical and social contexts and inter-relations (Tomlinson et al., 2018). In sharp contrast to the views of humans acting independently, Bourdieu $(1979,1984,1986)$ offers another perspective in this debate - of humans as constrained actors negotiating social fields. Bourdieu's theory of agency, an unsteady property of actors that emerge through shifting interactions of capital, habitus, and field, is discussed in this article as actions or behaviours that Māori used to navigate and negotiate a space of legitimacy in the mathematics education field.

Bourdieu (1984) is well-known in the field of education for his contributions to the area of cultural capital. While Bourdieu's definitions differ across the body of his work, the characteristic they share is reference to high-status cultural knowledge possessed by individuals (Bourdieu, 1984). Bourdieu's theory is useful in that it reinterprets inequalities in educational achievement as the outcome of socially determined differences in cultural capital (Cincinnato et al., 2016). For example, one difference between Māori and English-language schools' was their capacity to maintain continuity of mathematics instruction while schools were closed due to the COVID-19 pandemic. Bourdieu (1986) identified (at least) 
two other broad types of capital relevant to this study-economic and social. In education, economic capital refers to material resources including mathematics education resources, such as digital resources. According to Fraser (2005), socioeconomic injustices involve exploitation and economic marginalisation, and are associated with unequal distribution of material resources between social groups, which Fraser (2005) refers to as "maldistribution" where social goods such as education are distributed to different groups. Bourdieu (1984) conceptualised social capital as the networks and individual relationships across fields that potentially increase access to resources. This includes the power to influence the content of the mathematics curriculum and/or the language of schooling.

Bourdieu's solution to the structure-agency problem was the habitus (Bourdieu, 1986) which can be understood as an embodied social structure - that piece of social structure that we all carry around in our heads, and which largely regulates our actions. It originates from our lived experiences of class and the social structures within which we have become familiarised and socialised (Bourdieu, 1986). The field is another major concept used by Bourdieu. Field refers to social settings in which individuals and their stocks of capital are located. Fields are important because it is only within these contexts that we can understand how the rules of the field interact with individuals" "capitals" and their habitus to produce specific outcomes (Bourdieu, 1986). Fields in this context include social institutions such as the education system, government agencies, such as the Ministry of Education (MoE), and mathematics classrooms. A field is characterised by its own set of doxa, or dominant beliefs and "rules" (Bourdieu, 1984), specific history, institutionalised power formation, and by its determinate agents (e.g., students, teachers, MoE officials).

Proposing mathematics education as a field allows a range of external and internal influences to be analysed. Thus, mathematics education can be conceptualised by a field as such. The field of education is not autonomous (Calhoun et al., 1993). While the field of education does identify, value, and distribute its cultural capital, in Aotearoa NZ, it is constrained by the field of politics (those with the ultimate power). As we show here, fields are contexts and arenas of struggle for legitimacy or the right to monopolise the exercise of symbolic violence (Swartz, 1997). Symbolic violence, as defined by Webb (2002), is not physical, but instead, a symbolic form imposed on an individual or group. It can be in the form of people being denied resources, being treated as inferior, or being given limited opportunities. The key here is that the struggle is not just one for the available cultural capital, it is also a contest for the existence and identity of the mathematics education field itself, and for whether its rules and boundaries are changed or entrenched. Fields are the context in which "relations" between agents and structures are played out. Bourdieu (1984) argues that while our decisions may be our own (as agents), they are greatly guided and restricted by the social structure (fields) in which we exist.

There is a need to understand how agency-structure dynamics have created both barriers (maintaining status quo) and opportunities (transformative) for teaching mathematics in the Māori language, especially during this current pandemic. While Bourdieu is frequently criticised for giving insufficient attention to the question of how any habitus or structure can produce social transformations (see Sewell, 1992), Fowler (2020) argues that Bourdieu consistently claimed to offer a theory of social transformation as well as accounting for continuities of power. As example is his theory of the "corporatism of the universal": the role of intellectuals or other educated professionals in pursuit of social justice and other universalistic goals (Bourdieu, 1989). In the next section, we examine the emergence of the Māori-medium schooling era from the 1980s until 2020 to provide a context to explain the state of preparedness of Māori-medium schools teaching mathematics in the Māori language to contend with physical school closures in response to COVID-19. 


\section{Collective community agency as resistance: development of Mãori-medium schools}

The primary, although not exclusive, focus of Māori language revitalisation efforts dating back to the 1980s has been the re-instantiation of te reo Māori as the language of schooling and the teaching of subjects such as mathematics (Trinick \& May, 2013). In the early 1980s, Māori used their agency to advocate for some form of bilingual education among the few still predominantly Māori rural communities that remained, often in the face of stiff state and English-medium school's insistence on maintaining the status quo. These bilingual schools (which includes the school Piata attended), with support from their elders and local families, were trying to save the Māori language from extinction in their communities (Benton, 1984) and were able to achieve their goals through the exercise of both community and proxy agency. Through the strength of their own convictions (Bourdieu's habitus), these communities persuaded both the Minister of Education and influential senior officials in the Education Department (the MoE from 1991) that a few bilingual schools should be set up (Benton, 1984). While the MoE tacitly agreed to the use of Māori language as the language of instruction, these early bilingual schools were still required to follow the English-language mathematics syllabus for Aotearoa NZ schools with limited mathematics resources in the Māori language (Trinick, 2015).

Outside a few bilingual schools, most of the compulsory State education sector remained ambivalent about, or actively resisted, Māori community language aspirations (McMurchy-Pilkington \& Trinick, 2008). In response, small groups of Māori families across the country used their collective agency (Bandura, 2008); pooled their knowledge, skills, and resources; and developed Māori-medium schools outside the State system in garages and halls (Trinick, 2015). This created a Māori-centric alternative to State-funded English-language schooling, thereby shifting the "cultural capital" of schooling in favour of Māori language and culture. However, the State maintained considerable economic control by denying these schools' financial support. The number of these grassroots schools expanded rapidly throughout the 1980s, allied with political lobbying from Māori who were slowly gaining some economic and social capital and supportive non-Māori proxies, compelled the NZ government in 1989 to recognise these schools as a formal State-funded alternative to English-medium schooling at primary/elementary and secondary levels (Trinick \& May, 2013).

Māori-medium mathematics classrooms face similar challenges to bilingual and Indigenous mathematics learning programmes internationally. However, the Māori-medium mathematics classroom has distinctive characteristics. Many Māori-medium mathematics students, and concerningly, many teachers, are second language (L2) learners of the language of instruction, a legacy of decades of covert and overt language assimilation policies, whereby, over time, Māori language usage became restricted to a few language domains (Trinick et al., 2014). To combat the overwhelming prevalence of English-language use in the many social domains students interact in, and the fact that many students are L2 learners of Māori, many Māori-medium schools follow a monolingual instruction policy. Requiring, among other things:

That all subjects [are] to be taught only in the medium of Māori, and that there is a clear separation and division between time, place and speakers of English and Māori languages while discouraging such practices as mixing or 'code switching' of the two languages. (Department of Internal Affairs, 2008, p. 736) 
As a pedagogical approach, this policy is controversial and conflicts with bilingual instruction approaches (Cummins, 2000). One of the most compelling reasons for separating instruction languages is the concern that encouraging the use of both English and Māori in the same mathematics lesson will favour the more proficient language, typically, the home language or L1 (Trinick, 2015). For many of these learners, the Māori language is not yet autonomous. The strength of the Māori language in homes is variable; it is not the language of the majority or the language of power in larger society (Trinick, 2015).

The term "Māori-medium" is now used to refer to schools teaching subjects in the medium of the Māori language at least $50 \%$ of the time with level 1 Māori-medium schools defined as providing more than $80 \%$ of instruction in the Māori language (MoE, 2020a). All forms of Māori-medium schooling (early bilingual and then grassroots) are required to follow State-mandated mathematics curricula, a requirement for State funding (economic capital). This article focuses on level 1 Māori-medium schools who were tasked with providing $80 \%$ of remote instruction in the Māori language while schools were closed and the lack of suitable resources to do so.

In the early 1990s, 10 years after the emergence of Māori-medium schooling, the MoE initiated a curriculum reform agenda. Initially, no recognition was given to developing Māori-medium mathematics curriculum (Trinick et al., 2015). There was no appreciation of the specific linguistic needs and cultural knowledge revival aspirations of the Māorimedium schooling community, even though Māori-medium schools had functioned as State-mandated for approximately a decade. Recognition injustices can be conceptualised as "ideologies and norms that classify some groups of people as worth less respect than others" (Nelund, 2011, p. 63). To address these injustices requires a politics of recognition (Fraser, 2003)—close to Bourdieu's symbolic violence, because those excluded are denied part of what it is to be fully human. For Bourdieu (2000), misrecognition refers to an everyday and dynamic social process where one thing (such as Indigenous curriculum) is not recognised for what it is because it was not previously "cognised" within the range of dispositions and propensities of the habitus of the person(s) confronting it (James, 2015).

A range of misrepresentative decisions were made by the MoE, denying the Māorimedium sector the right to participate meaningfully and substantively in mathematics curriculum development decision-making. This misframing created what Fraser (2003) considers representation-related injustices or "political voicelessness", and these are becoming increasingly important to consider in struggles for justice and democracy in a globalised world. This misframing created multiple forms of voicelessness among key Māori stakeholder groups, and these filtered out to justify, perpetuate, and deepen other types of injustice-particularly misrecognition (Fraser, 2003).

After intense lobbying by key Māori-medium education stakeholder groups, the then Minister of Education acquiesced to the development of a mathematics curriculum in the Māori language. However, the initial excitement was tempered by the MoE's contractual requirement that the structure of the new mathematics curriculum had to "mirror" the hegemonic English-medium versions (McMurchy-Pilkington \& Trinick, 2002). In the 1990 s, the political agenda was concerned with new forms of governance in education and the concept of accountability through assessment.

While this recognition was agreeable on one level as this was the first time that Māori educationalists were given some authority, however delimited, to develop State curricula (Trinick \& May, 2013), the Māori-medium mathematics curriculum still had to have the same structure and content (McMurchy-Pilkington \& Trinick, 2002). The developers recognised that for credentialing purposes, for example, entry into university, Māori-medium graduates would still be required to have achieved in areas such as algebra and calculus. 
One of the key issues was that this development ignored one of the key goals of Māorimedium schooling, which was the revitalisation of Māori cultural knowledge. Essentially, the Māori-medium sector was presented with an unenviable dilemma-either work within the parameters determined by the MoE or implement the new English-medium curriculum versions. The Māori-medium community was thus left with arguably no choice but to make the best of it which was indeed a bitter pill.

However, Māori-medium mathematics curriculum developers saw an opportunity to coopt the development of a Māori-medium mathematics curriculum and used their collective, but limited, agency to serve their community's linguistic needs. For example, the development of the Māori-medium mathematics register enabled the teaching of mathematics, in the Māori language, to the upper level of secondary schools and beyond (McMurchy-Pilkington et al., 2013). With implementation of the Māori-medium mathematics curriculum a requirement under legislation by the late 1990 s, the MoE was also obliged to support teachers and schools through a range of initiatives, including professional development and resources to support Māori-medium mathematics education.

The second round of development of Māori-medium curricula in 2007-2008 had a different starting point. While the basic structure of the 1996 curricula was to be maintained, the earlier restrictive requirements, for example, that it had to be a translation of the English version, were removed (McMurchy-Pilkington et al., 2013). The capacity to develop Māorimedium curriculum had expanded significantly over the intervening decade and the "Ministry of Education appeared more accommodating of difference" (McMurchy-Pilkington et al., 2013 , p. 357). There had been numerous political and educational changes over the previous 13 years that facilitated this change, including greater political recognition and representation (McMurchy-Pilkington et al., 2013, p. 357). Although curriculum was still mandated by the $\mathrm{MoE}$ and passed down to schools to operationalise, schools now had more flexibility in how they implemented the curriculum. Thus, one of the areas the MoE was supportive of was to allow schools to "localise" the national curriculum and adjust curriculum requirements accordingly (Trinick et al., 2015).

State support is still inadequate in addressing all the challenges of teaching mathematics in the Māori language, for example, mathematics teacher supply; therefore, the Māori-medium mathematics community continues to use its collective agency to promote the teaching and learning of mathematics in Māori. Despite the structural challenges, the Māori language has been reintroduced as the medium of instruction after being absent for more than 100 years. It is now possible to teach mathematics up to the end of secondary school in the Māori language—not thought possible 30 years ago by many critics (Trinick, 2015). This has helped raise the status of Māori-medium schooling. In the following section, we discuss the current COVID-19 pandemic context and the agentic responses of the Māori-medium mathematics community to ensure the continuation of Māori-medium mathematics education despite the entrenched structural limitations imposed by the State.

\section{The COVID-19 pandemic context}

On March 17, 2020, the Aotearoa NZ Ministry of Health identified the first case of COVID19 in a school (New Zealand Government, 2020). Over the following days, alarmingly, more cases were identified and individual schools and programmes in universities began to suspend teaching. On March 23, the government announced that all schools and early childhood centres would close within $48 \mathrm{~h}$ with no one allowed on site (NZ Government, 2020). 
This allowed 2 days for schools to prepare for an unprecedented total lockdown, whereby the whole nation was ordered to isolate by staying at home to stem the community spread of COVID-19 and a national state of emergency was declared. The notice to lockdown was abrupt, and many schools and communities were caught totally unprepared. The lockdown period posed significant learning and teaching challenges for Māori-medium schools and communities, with the necessity for all students to learn in isolation utilising digital technology wherever possible. From our experience as mathematics educators, many Māori-medium schools had minimal, if any, experience teaching and learning mathematics remotely using digital technology, particularly at the primary school level.

Lockdown restrictions were partially lifted 4 weeks later on April 27 (NZ Government, 2020), allowing schools to reopen with significant health and safety measures including physical distancing and classes limited to 10 students. Restrictions were lifted further on May 13 as was the national state of emergency (NZ Government, 2020). Physical distancing in public spaces was still required, and the size of public gatherings was limited. At this point, the Aotearoa NZ collectively breathed a huge sigh of relief even though the virus was yet to be totally eradicated. Most of the remaining domestic restrictions were removed on June 9, while border restrictions remained in place, and COVID-19 testing policies for those crossing the border were tightened (Ministry of Health, 2020).

After 102 days free of community transmission, four community cases of the virus were reported on August 11 in Auckland, Aotearoa NZ's most populated city (Ministry of Health, 2020). The following day, Auckland schools remained open with limited capacity, and remote learning programmes resumed in the region. Travel to and from Auckland was also restricted, effectively creating an Auckland bubble (NZ Government, 2020). The rest of the country's schools remained open with physical distancing measures, and public gathering limits reinstated until September 31 (NZ Government, 2020). Restrictions in Auckland were partially lifted on September 30, with schools able to resume full capacity. The remainder of the domestic travel restrictions and group gathering limits was once again lifted for Auckland on August 7.

In comparison to many other countries around the world, current mortality and infection rates for Māori and the general population are proportionally very low. This can be attributed to several factors including a unique geography, an empathic political leader, and the collective agency of the government and its citizens. Aotearoa NZ as a group of islands has the advantage of being relatively isolated at the bottom of the world, which meant fewer early travellers from other infected areas and a longer time before cases started to appear. Thus, the government had more control over who could enter compared to countries with large and porous land borders. Aotearoa NZ's low population density of 5 million, with the exception of a few large urban areas scattered across the country, meant it may have been harder for the virus which is transmitted via close contact and airborne respiratory droplets to spread (Ministry of Health, 2020).

It was clear that the Prime Minister recognised the alarming health threat of COVID19 to New Zealanders and quickly deferred to saving peoples' lives despite significant economic disruption. In directing New Zealanders to "stay home to save lives", the Prime Minister simultaneously offered meaning and purpose to what citizens were being asked to do (Menon, 2020). The Prime Minister acknowledged the challenges that staying home would have on families, including separation from loved ones and the dangers the pandemic posed to lives and livelihoods, particularly for Māori and Pasifika peoples. There was generally an absence of noise from political leaders speaking differently to health advisors, local authorities, school boards, and parents. Publicly, the Prime Minister was supported by the majority of citizens who understood that only a few mitigation strategies 
were available to a small country such as Aotearoa NZ and that they all required societal support.

Certain cultural factors also make Aotearoa NZ unique, such as a high level of public cooperation. According to one poll, the citizens of Aotearoa NZ place a high level of trust in the government (Colmar Brunton, 2020), with $88 \%$ of New Zealanders surveyed trusting the government to make the right decisions about COVID-19. While the lockdowns and the requirement to self-isolate impacted significantly on the quality teaching and learning of mathematics, the negative impact was disproportionate across the various communities. In the following sections, we examine why the impact was variable across communities which relates to the historical struggle between State institutions to maintain dominance and Māori communities' emancipatory efforts to create space to teach and learn mathematics education in the Indigenous language. An emphasis on historicity places an analytical priority on "agents and agency", that is, the efforts of those to mediate language and cultural revitalisation.

\section{Structural challenges limiting the capacity to provide remote mathematics instruction}

Māori and the rest of the Aotearoa NZ population can rejoice in the very positive health outcomes compared to the cataclysmic outcomes seen in many other countries during the pandemic; however, Aotearoa NZ is by no means a sociocultural utopia. The COVID-19 pandemic has unmasked disparities in communities that have existed in Aotearoa NZ for generations in sectors such as health care, employment, housing, and specifically the focus of this article, mathematics education. From our experience as mathematics educators, many Māori-medium schools had minimal, if any, experience teaching and learning mathematics online prior to the pandemic, particularly at the primary school level. While there were potentially useful developments for remote education for Māori-medium mathematics, these were largely attempts to replicate face-to-face instruction and traditional classroom-style practices.

The Māori-medium sector has for some time been lobbying the MoE for an adequate pool of digital mathematics resources (Trinick \& Parangi, 2007). This is because Māorimedium schools are generally small, geographically or linguistically isolated (located in English-language dominant urban areas), and draw students from lower socioeconomic communities. During the COVID-19 lockdown period, the need for easily shareable digital resources was further exacerbated by school closures, and all Māori-medium students are required to learn in isolation in their respective bubbles. Due to the monolingual policy requirement of many Māori-medium schools that learning and teaching must only be in Māori $80 \%$ of the time, a lack of readily available digital resources and the associated professional development for teaching mathematics online in the Māori language at all levels of the curriculum was acutely felt by level 1 Māori-medium schools.

Initiatives had been launched prior to the arrival of COVID-19 to support distance learning in Māori-medium mathematics in the early 2000s, when a video conferencing network was implemented to address the chronic shortage of senior secondary Māori-medium mathematics teachers (Waiti, 2005). Although well intentioned, a number of schools could not use the equipment effectively because of a lack of available bandwidth; teaching was synchronous causing timetabling issues, schools made minimal attempts to recruit teachers (relying on video conferencing to essentially babysit), and over time, the equipment 
aged and interest generally dwindled. Students did not react well to learning mathematics essentially through the pedagogy of a lecture and, when unsupervised, took the opportunity to disengage (Trinick \& Parangi, 2007). This programme has continued, albeit on a much smaller scale, involving a few schools (Waiti, 2005). However, the system was of no use for remote learning during the pandemic because equipment was situated in schools and therefore inaccessible.

Subsequent to the video conferencing era, the concept of e-learning, "learning and teaching that is facilitated by or supported through the smart use of information and communication technologies" (MoE, 2009, p. 2), became the focus for the Aotearoa NZ education system in response to facilitating the goal of twenty-first century learning within a ubiquitous digital environment (Newton, 2018). There was an assumption that the benefits of using digital technology would naturally transfer to the Māori-medium sector (Murphy \& Reid, 2016). However, there is minimal scientific research into the practice of using digital tools to support the Māori-medium mathematics context (Allen, 2015; Christensen, 2004; Meaney et al., 2012; Trinick, 2015). There are even fewer studies examining digital technology use that supports the acquisition of mathematics and of Māori language and culture. This is significant, because many students and teachers in Māori-medium education are L2 learners of the language of instruction (Christensen, 2004). Therefore, Māorimedium mathematics students and teachers require opportunities to acquire mathematics language alongside mathematics content and concepts (Allen, 2015). Second language acquisition pedagogical approaches such as providing language models prior to, or alongside, learning tasks (Willis, 2005) can alleviate the language challenges of learning mathematics content in an L2, particularly if multiple representations of mathematics language are provided (Allen, 2015). English-medium mathematics education research often defaults to assuming first language instruction and fails to address the unique linguistic challenges of the Māori-medium mathematics learning environment (Allen, 2015; Murphy \& Reid, 2016; Tiakiwai \& Tiakiwai, 2010), such as the pre-existing lack of digital mathematics resources in the Māori language.

Prior to the pandemic, a survey conducted by Murphy and Reid (2016) of Māorimedium teachers found that digital devices were used minimally in Māori-medium learning environments during a typical school week. Cost and staff capability were cited as barriers to using digital technology in Māori-medium learning programmes (Murphy \& Reid, 2016). Murphy and Reid (2016) found that older students are more likely than younger students to use devices for learning, and only $50 \%$ of Māori-medium students had access to the Internet at home, with most Māori-medium students having access to shared devices only at school. While shared devices may mitigate issues of digital technology access at school, the usefulness of shared devices is nullified when schools are closed. Resources that were readily available in the Māori language and contained learning contexts that reflected the realities of Māori-medium students were mostly textbook based, not digital.

There are currently very few dynamic Māori language mathematics applications available. The few that exist are primarily translated drill and practice type apps that are game based but do not address L2 language development (other than reading and responding to instructions) (Trinick et al., 2016). There are often costs associated with using translated apps, and more often than not, visuals are not contextualised and do not reflect Māori culture and identity (Trinick et al., 2016), instead covertly maintaining the dominant "cultural capital" of English-language education. Despite the self-imposed language separation policy, the Māori-medium sector is often forced to default to English-language mathematics resources due to lack of digital content available in Māori. This can cause concern among school leaders who are apprehensive about encouraging widespread use of digital 
technology, due to the potential erosion of their Māori language dominant learning environment through the use of English-language software. In some Māori-medium schools, English-language apps are the only vehicle for English-language instruction outside of formal English-language lessons.

In summary, when the pandemic struck, the Māori-medium schooling infrastructure did not have the immediate capacity to provide culturally relevant and sufficiently challenging remote mathematics learning in the Māori language. As discussed earlier, the issue of a limited bank of digital mathematics resources in the Māori language is not a result of the pandemic - it is a legacy of over 100 years of assimilationist practices banning the use of the heritage language, followed by 30 years of under-resourcing of Māori-medium schooling. It is also a consequence of the ongoing education policies of the State-essentially to maintain the dominant cultural and social capital (Bourdieu, 1984) of European New Zealanders. While Māori-medium school communities had limited access to digital resources designed to teach mathematics specifically, teachers, parents, students, and communities quickly responded to use their collective agency to support the teaching and learning of mathematics in the Māori language by utilising the digital resources they had access to. The following sections discuss how the Māori-medium sector used their agency to cope with the learning and teaching of mathematics, including the efforts of key stakeholder groups such as the MoE, mathematics educators, and Māori-medium sector communities and parents. We draw on our own experiences and observations as parents, whānau (family) members, teachers, and initial teacher educators to give further insight about these issues.

\section{How Māori-medium school communities used their agency to support remote learning}

When lockdown became a reality, the MoE was the principal agency charged with supporting children to learn from home. While support for Māori-medium was not equitable, the fact that all Māori-medium schools are now State-funded and are thus required to follow State-mandated curriculum encouraged a modicum of support. This included ramping up broadcast television shows utilising the partly State-funded Māori television service, which ironically included many former Māori-medium teachers and graduates having been attracted to the media profession. They were able to quickly create resources for guiding Māori-medium mathematics to support parents to teach mathematics in homes (MoE, 2020b, c, d). These resources were based on the number framework used in Māori-medium schools to guide teacher planning and assessment (Trinick \& Stephenson, 2010). It is questionable whether parents understood the technical language of these resources. The issue of the language proficiency of parents is discussed later.

The MoE also sent out hard copy learning packs which contained text resources when requested by parents. Priority was given to families from lower socioeconomic areas, on the assumption it would be these families who would have limited access to technology at home. The problem with this assumption for Māori-medium schooling is that these schools do not necessarily draw many students from the geographic location of the school. Māorimedium schools are scattered across cities and often located in higher socioeconomic areas. Many students bus in from lower socioeconomic areas. This fact was totally overlooked causing considerable consternation in the Māori-medium community. 
The other mitigation strategy employed by the MoE was to reduce the structural barriers schools and teachers had to negotiate to receive support from professional facilitators with expertise in remote learning. However, the MoE had just gutted its professional learning and development offerings, and while the English-medium sector flourished (big schools with many students), the Māori-medium sector atrophied (small schools with few students). Thus, when the country went into lockdown, very few Māori-medium mathematics professional learning development facilitators were available, most having sought more stable employment elsewhere.

From our observations, social media groups became default communities of learning. Media content including new words and resources were quickly shared and tested nationally on social media platforms. The potential of these platforms and other similar virtual learning spaces for connecting students who are learning mathematics in isolation is yet to be fully understood (Ball \& Barzel, 2018). However, online Māori language communities have become increasingly important for Māori-medium schools operating in rural communities and those who are linguistically isolated in English-speaking urban areas. There has also been some recent investment designed to increase Māori language in new media and support language and culture outcomes in homes and communities (Te Māngai Pāho, 2020; Te Mātāwai, 2020). Language experts and production companies already producing content for social media platforms responded within the first week of the lockdown period with Māori language content designed to support the families of Māori-medium students. While this content was appreciated, it did not have an explicit focus on mathematics learning beyond that used in everyday household tasks such as cooking or exercising. Historically, and during this lockdown period, the Māori-medium community had to draw on its own limited resources (see Meaney et al., 2012) - in the case of mathematics, there was a lack of subject specialist expertise.

During the lockdown period, an online survey was carried out by an independent research company that asked parents of Māori and Pasifika students to comment on their experiences of school-led learning at home during the first week of the lockdown (RiwaiCouch et al., 2020). The survey highlighted equity issues for Māori families who did not have adequate access to devices, stationery, and the Internet. Many families were also juggling the pressures of parents working from home, while at the same time trying to support their children's learning, including mathematics. There are a large number of online sites dedicated to supporting parents to teach their children mathematics, but these are almost exclusively in English.

Riwai-Couch and colleagues' (2020) survey also highlighted concerns by Māorimedium parents about their own Māori language proficiency. Most parents in Māorimedium education are from generations of families who experienced their schooling in English and may have acquired the Māori language subsequently as adult learners. While many parents have a modicum of Māori language, enough to hold a conversation, most do not have the specialised mathematics language as it is not commonly used outside of the school domain (Meaney et al., 2012). However, during the pandemic, many used the opportunity to upskill themselves in trying to teach mathematics in the Māori language as best they could (Riwai-Couch et al., 2020). One strategy used by many parents to upskill during the lockdown period was accessing informal Māori language learning groups on social media as discussed earlier.

In addition to providing access to translated mathematics apps or English-language versions, a few Māori-medium schools utilised video calling software and learning management systems to enable synchronous and asynchronous recording and sharing of digital learning content. This created opportunities for teachers to create digital language models 
with multiple representations of mathematics language and to share these within the Māorimedium mathematics learning community.

While Māori-medium teachers, students, and parents who had access to devices and the Internet were engaged in producing digital mathematics artefacts, not all students had access to devices. Some tribes used their tribal agency to identify those members who did not have adequate access to devices and sent devices to the affected students. This was the case for the principal tribe that has authority in Auckland. The tribe conducted a survey into the online learning challenges faced by their constituents (Hunia et al., 2020). As a consequence, they could target families who required support with the technology to learn online. A number of tribes have received settlements of resources as a result of decades of depriving them of their cultural and economic property rights, thus enabling them to become major entrepreneurial players to support their constituents. However, many tribes are not in a financial position to support all of their membership in this way.

Finally, structural constraints (material) as a result of procedures applied in the reproduction of social practices (Giddens, 1984), such as English-only schools for decades, meant many teachers were unprepared to teach remotely, that few digital resources were available in the Māori language, and teachers and parents used the skills they did have (being resourceful) to provide a meaningful mathematics programme of some sort. While variable in quality, it showed that in times of extreme adversity, the Māori-medium mathematics education community used their individual and collective agency to ensure children's learning was not too adversely affected.

\section{Where to from here?}

For decades, there has been misrepresentation in mathematics education of Māori cultural and linguistic aspirations - first during the English-only schooling period up to the 1980s and continuing in the Māori-medium era to this day. When Māori-medium education emerged in the 1980s, it was still not directly represented in positions of power and influence in the government, the MoE, and the mathematics education community generally. For example, acknowledging and incorporating the cultural element of subjects such as mathematics (ethnomathematics) is often met with strong resistance (Barton, 2008), particularly from mathematicians and mathematics educators who view mathematical thought as universal and culture-free (Ernest, 1991). This relates to Bourdieu's concept of doxa (common belief) in the field of mathematics education, which in turn influences beliefs at various levels of society both at the macro- and micro-levels. Thus, a range of misrepresentative (or misrecognition, Bourdieu, 1984) decisions were made, denying the Māorimedium sector the right to participate meaningfully and substantively in cultural and economic decision-making for schools. This misframing created what Fraser (2003) considers representation-related injustices, or "political voicelessness"; this created multiple forms of voicelessness among key Māori stakeholder groups. These justified, perpetuated, and deepened other types of injustices-particularly misrecognition, which was to have far-reaching consequences for the revitalisation of Māori knowledge, production of resources, and professional development such as the knowledge and skill required to teach and learn remotely when the pandemic arrived in early 2020 .

Looking forward, we reflect on how to future-proof Māori-medium mathematics against times of disruption such as those caused by pandemics, but more strongly, we argue that this can only be achieved by the restructuring of a more equitable education system for 
Māori-medium education. Providing continuity in delivery of mathematics learning programmes in the Māori language was hampered by a lack of access to digital resources in the Māori language. For example, while some Māori-medium students were engaged in digital mathematics content creation and consumption when schools were closed, others lost access. When access was possible, some Māori-medium learning programmes defaulted to providing English-language mathematics apps in the absence of resources in the Māori language, continuing to promote the cultural capital inherent in English-language schooling. In cases where translated apps were provided, the visuals and contexts did not reflect Māori culture and identity. Ideally, any digital resources provided to Māorimedium students should be designed to reflect Māori student experiences and privilege Māori cultural capital.

The lockdown period has required more intensive use and therefore ad hoc development of digital Māori language content by teachers, students, and school communities, which is not necessarily a negative outcome. Māori-medium teachers and students used their collective agency to create and share new resources and used the opportunity to learn more about effective pedagogy for remote learning. However, this is not sufficient to address all of the shortcomings of delivering an effective mathematics education programme if we enter another lockdown period which is almost a certainty. Placing the burden of digital mathematics resource creation solely on the Māori-medium sector itself, rather than State agencies providing an adequate pool of purpose-built digital mathematics resources, is not equitable.

While Māori-medium educators have a legacy of using their collective agency to provide for their own needs, the COVID-19 pandemic has highlighted the significant underresourcing of the sector, particularly in the area of digital mathematics resources. Further research is required into how digital resources could be used to promote the acquisition of mathematics content and concepts and Māori language, all while supporting language separation and Māori-centric schooling. This research could inform future policy development and professional learning for teachers, and perhaps parents as teachers.

Finally, there is an opportunity to explore how parents and teachers might use their collective agency to work more productively together in the context of family homes, and how learnings from the current situation might transfer back to schools and education generally. Thus, there is a need to engage with the community of parents and caregivers who have had to use their agency to manage the simultaneous challenges of being a parent in a time of crisis, enforced working from home, or surviving when they have lost their jobs. To conclude, the main principle underlying the autonomous approach is the capacity to exercise the power of decision-making which requires non-Indigenous groups to surrender their historic power and remove the various pressures of structural dominance over Indigenous people (Bourdieu, 1984; Heslop, 1998).

\section{Declarations}

Conflict of interest The authors declare no competing interests.

\section{References}

Allen, P. (2015). Te reo pāngarau: Communicating mathematically in Māori-medium classrooms [Master's dissertation, University of Auckland]. http://hdl.handle.net/2292/26542. Accessed 8 Aug 2021. 
Ball, L., \& Barzel, B. (2018). Communication when learning and teaching mathematics with technology. In L. Ball, P. Drijvers, S. Ladel, H. S. Siller, M. Tabach, \& C. Vale (Eds.), Uses of technology in primary and secondary mathematics education. https://doi.org/10.1007/978-3-319-76575-4_12

Bandura, A. (2008). An agentic perspective on positive psychology. Positive Psychology, 1, 167-196.

Barber, K. (1986). Employment and race relations policy in New Zealand: A critique [Unpublished doctoral dissertation]. University of Auckland.

Barker, C. (2005). Cultural studies: Theory and practice. Sage.

Barton, B. (2008). Cultural and social aspects of mathematics education: Responding to Bishop's challenge. In P. Clarkson \& N. Presmeg (Eds.), Critical issues in mathematics education (pp. 121-133). Springer.

Bauer, W. (1993). Māori. Routledge.

Benton, R. (1979). Who speaks Māori in New Zealand? New Zealand Council for Educational Research.

Benton, R. A. (1984). Bilingual education and the survival of the Maori language. The Journal of the Polynesian Society, 93(3), 247-266.

Benton, R. (1991). The history and development of the Māori language. In G. McGregor, M. Williams, \& R. Harlow (Eds.), Dirty silence: Aspects of language and literature in New Zealand (pp. 187199). Cambridge University Press.

Bourdieu, P. (1977). The economy of linguistic exchanges. Social Science Information, 16, 645-668.

Bourdieu, P. (1979). Symbolic power. Critique of Anthropology, 4(13-14), 77-85.

Bourdieu, P. (1984). Distinction. Routledge.

Bourdieu, P. (1986). The forms of capital. In J. Richardson, (Ed.), Handbook of theory and research for the sociology of education (pp. 241-258). Greenwood.

Bourdieu, P. (1989). Social space and symbolic power. Sociological Theory, 7(1), 14-25.

Bourdieu, P. (1991). Language and symbolic power. Polity Press.

Bourdieu, P. (1999). Scattered remarks. European Journal of Social Theory, 2(3), 334-340.

Bourdieu, P. (2000). Pascalian meditations. Stanford University Press.

Calhoun, C., LiPuma, E., \& Postone, M. (1993). Bourdieu: Critical perspectives. University of Chicago Press.

Chrisp, S. (2005). Māori intergenerational language transmission. International Journal of the Sociology of Language, 172, 149-181.

Christensen, I. (2004). Exploring issues in mathematics education: An evaluation of Te Poutama Tau 2003. Ministry of Education. https://nzmaths.co.nz/sites/default/files/Numeracy/References/eval_ tpt2003.pdf. Accessed 8 Aug 2021.

Cincinnato, S., De Wever, B., Van Keer, H., \& Valcke, M. (2016). The influence of social background on participation in adult education: Applying the cultural capital framework. Adult Education Quarterly, 66(2), 143-168.

Colmar Brunton. (2020). Covid times. https://static.colmarbrunton.co.nz/wp-content/uploads/2019/05/ COVID-Times-24-April-2020.pdf. Accessed 28 May 2020.

Cummins, J. (2000). Language, power, and pedagogy: Bilingual children in the crossfire (Vol. 23). Multilingual Matters.

Department of Internal Affairs. (2008). Official version of Te Aho Matua o Ngā Kura Kaupapa Māori and explanation in English. The New Zealand Gazette, 32, 734-746. http://www.dia.govt.nz/pubfo rms.nsf/NZGZT/Supplement_TeAho32Feb08.pdf/\$file/Supplement_TeAho32Feb08.pdf. Accessed 8 Aug 2021.

Edwards, J. (1994). Multilingualism. Routledge.

Ernest, P. (1991). The philosophy of mathematics education. The Falmer Press.

Fishman, J. A. (1991). Reversing language shift: Theoretical and empirical foundations of assistance to threatened languages (Vol. 76). Multilingual Matters.

Fowler, B. (2020). Pierre Bourdieu on social transformation, with particular reference to political and symbolic revolutions. Theory and Society. https://doi.org/10.1007/s11186-019-09375-z

Fraser, N. (2003). Social justice in the age of identity politics: Redistribution, recognition, and participation. In N. Fraser \& A. Honneth (Eds.), Redistribution or recognition? A political-philosophical exchange (pp. 1-99). Verso.

Fraser, N. (2005). Reframing justice in a globalizing world. New Left Review, 36(Nov-Dec), 69-88.

Giddens, A. (1984). The constitution of society. Polity Press.

Heslop, J. (1998). Making the schools relevant: School and community in partnership. In G. Partington (Ed.)., Perspectives on Aboriginal and Torres Strait Islander education (pp. 274-293). Social Science Press. 
Hunia, R., Salim, S., McNaughton, S., Menzies, R., Gluckman, P., \& Bardsley, A. (2020). Addressing rangatahi education: Challenges after COVID-19. https://www.auckland.ac.nz/en/news/2020/07/ 29/addressing-rangatahi-education-challenges-after-covid-19.html. Accessed 8 Aug 2021.

James, D. (2015). How Bourdieu bites back: Recognising misrecognition in education and educational research. Cambridge Journal of Education, 45(1), 97-112.

King, P., Cormack, D., McLeod, M., Harris, R., \& Gurney, J. (2020). COVID-19 and Māori health - When equity is more than a word. Te Rōpū Whakakaupapa Urutā: Māori Pandemic Response Group. https:// www.uruta.maori.nz/when-equity-is-more-than-a-word. Accessed 28 May 2020.

May, S. (2011). Bourdieu and language policy. In M. Grenfell (Ed.), Bourdieu: Language and linguistics (pp. 147-169). Continuum.

May, S., \& Hill, R. (2005). Māori medium education: Current issues and challenges. International Journal of Bilingual Education and Bilingualism, 8(5), 377-403.

McMurchy-Pilkington, C., \& Trinick, T. (2002). Horsepower or empowerment: Mathematics curriculum for Maori-Trojan horse revisited. In B. Barton, K. C. Irwin, M. Pfannkuch, \& M. O. J. Thomas (Eds.), Mathematics education in the South Pacific: Proceedings of the 25th Annual Conference of the Mathematics Education Research Group of Australasia (pp. 465-472). https://www2.merga.net.au/node/38? year=2002. Accessed 8 Aug 2021.

McMurchy-Pilkington, C., \& Trinick, T. (2008). Potential \& possibilities. In V. Carpenter, J. Jesson, P. Roberts, \& M. Stephenson (Eds.), Ngā kaupapa here: Connections and contradictions in education (pp. 133-144). Cengage Learning.

McMurchy-Pilkington, C., Trinick, T., \& Meaney, T. (2013). Mathematics curriculum development and Indigenous language revitalisation: Contested spaces. Mathematics Education Research Journal, 25(3), 341-360.

Meaney, T., Trinick, T., \& Fairhall, U. (2012). Collaborating to meet language challenges in indigenous mathematics classrooms. Springer.

Menon, P. (2020, March 30). Ardern's online messages keep spirits up in New Zealand's coronavirus lockdown. Reuters. https://www.reuters.com/article/us-health-coronavirus-newzealand/arderns-online-messa ges-keep-spirits-up-in-new-zealands-coronavirus-lockdown-idUSKBN21H0HN. Accessed 28 May 2020.

Ministry of Education. (2009). Information and communication technology. Author.

Ministry of Education. (2020a). Māori language in schooling. https://www.educationcounts.govt.nz/stati stics/6040. Accessed 28 May 2020.

Ministry of Education. (2020b). 5-8 nohinohi: Ki te Ao Mārama. https://www.kauwhatareo.govt.nz/en/ resource/ki-te-ao-marama/5-8-nohinohi/. Accessed 28 May 2020.

Ministry of Education. (2020c). Home learning TV I Papa kāinga TV. https://learningfromhome.govt.nz/ learning-resources/home-learning-tv\#M\%C4\%81oriTelevision-te-reo-content. Accessed 28 May 2020.

Ministry of Education. (2020d). Kia manawaroa. https://www.education.govt.nz/kia-manawaroa/. Accessed 28 May 2020.

Ministry of Health. (2020). COVID-19 (Novel coronavirus). https://www.health.govt.nz/our-work/diseasesand-conditions/covid-19-novel-coronavirus. Accessed 8 Aug 2021.

Murphy, H., \& Reid, D. (2016). Ngā Hangarau Matihiko i ngā Kura Ara Reo Māori । Māori-medium ICT research report 2016: Digital technologies. Ministry of Education. https://www.educationcounts.govt.nz/ publications/91416/105966/nga-hangarau-matihiko-i-nga-kura-ara-reo-maori. Accessed 28 May 2020.

Nelund, A. (2011). Finding a theory of justice for Canada's Truth and Reconciliation Commission. The Annual Review of Interdisciplinary Justice Research, 2, 55-71.

Newton, C. (2018). Towards digital enablement: A literature review. Ministry of Education. https://www. educationcounts.govt.nz/publications/schooling/towards-digital-enablement-a-literature-review. Accessed 28 May 2020.

New Zealand Government. (2020). History of the COVID-19 alert system. https://covid19.govt.nz/alert-system/history-of-the-covid-19-alert-system/. Accessed 8 Aug 2021.

Riwai-Couch, M., Bull, A., Ellis, B., Hall, K., Nicholls, J., Taleni, T., \& Watkinson, R. (2020). School-led learning at home: Voices of the parents of Māori and Pasifika students. Evaluation Associates. http:// www.evaluate.co.nz/key-readings/school-led-learning-voices-of-parents-of-maori-and-pasifika-stude nts. Accessed 28 May 2020.

Sewell, W. H., Jr. (1992). A theory of structure: Duality, agency, and transformation. American Journal of Sociology, 98(1), 1-29.

Simon, J. (1998). Ngā kura Māori: The Native Schools system 1867-1969. Auckland University Press.

Smith, L. T. (1996). Ngā aho o te kakahu matauranga: The multiple layers of struggle by Māori in education [Doctoral dissertation, University of Auckland]. ResearchSpace. http://hdl.handle.net/2292/942. Accessed 8 Aug 2021. 
Smith, G. H. (2000). Maori education: Revolution and transformative action. Canadian Journal of Native Education, 24(1), 57-72.

Spolsky, B. (2003). Reassessing Māori regeneration. Language in Society, 32(4), 553-578.

Swartz, D. (1997). Culture and power: The sociology of Pierre Bourdieu. University of Chicago Press.

Te Māngai Pāho. (2020). New media. https://www.tmp.govt.nz/new-media. Accessed 28 May 2020.

Te Mātāwai. (2020). Te Mātāuru ki Te Reo Tukutuku: The Te Reo Tukutuku investment plan. https://www. tematawai.maori.nz/te-reo-tukutuku-mi. Accessed 28 May 2020.

Tiakiwai, S., \& Tiakiwai, H. (2010). A literature review focused on virtual learning environments (VLEs) and e-learning in the context of te reo Māori and kaupapa Māori education. Social Wellbeing Agency. https://thehub.swa.govt.nz/assets/documents/42612_LitRev-VLEs-FINALv2_0.pdf. Accessed 28 May 2020.

Tomlinson, J., Baird, M., Berg, P., \& Cooper, R. (2018). Flexible careers across the life course: Advancing theory, research and practice. Human Relations, 71(1), 4-22. https://doi.org/10.1177/0018726717 733313.

Trinick, A. (2015). Te Reo Tātai: The development of a mathematics register for Māori-medium schooling [Doctoral dissertation, University of Waikato]. Research Commons. https://hdl.handle.net/10289/9593. Accessed 8 Aug 2021.

Trinick, T., \& Parangi, P. (2007). Te Poutama Tau evaluation report. Ministry of Education.

Trinick, T., \& Stephenson, B. (2010). Evaluation of Te Poutama Tau: Māori-medium, numeracy project, 2003-2009. In D. Holton, K. Irwin, \& C. Linsell (Eds.), Findings from the New Zealand numeracy projects (pp. 72-87). Learning Media.

Trinick, T., \& May, S. (2013). Developing a Māori language mathematics lexicon: Challenges for corpus and status planning in indigenous contexts. Current Issues in Language Planning, 14(3-4), 457-473.

Trinick, T., Meaney, T., \& Fairhall, U. (2014). Teachers learning the registers of mathematics and mathematics education in another language: An exploratory study. ZDM-Mathematics Education, 46(6), 953-965.

Trinick, T., Meaney, T., \& Fairhall, U. (2015). Haere ana koe ki hea? Spatial thinking: Traditional Māori systems and language of spatial orientation. In R. Averill (Ed.), Mathematics and statistics in the middle years: Evidence and practice (pp. 146-161). NZCER Press.

Trinick, T., Allen, P., Taplin, B., \& Pipi, A. (2016). He puawaitanga harakeke - Using technology to accelerate learning in indigenous language schools. Paper presented at the 13th International Congress on Mathematical Education, Hamburg, Germany.

Waiti, P. (2005). Evaluation of Kaupapa Ara Whakawhiti Mātauranga. Ministry of Education.

Webb, V. N. (2002, April 16-20). Language policy development in South Africa [Paper presentation]. World Congress on Language Policies, Barcelona, Spain. https://www.linguapax.org/wp-content/uploads/ 2015/09/CMPL2002_T3_Webb.pdf. Accessed 8 Aug 2021.

Willis, J. (2005). A framework for task-based learning (9th ed.). Pearson.

Publisher's note Springer Nature remains neutral with regard to jurisdictional claims in published maps and institutional affiliations. 